\title{
WHAT BILL OF RIGHTS?
}

\author{
Austen Morgan, Barrister ${ }^{1}$ and Member of the Inn of Court of \\ Northern Ireland
}

\begin{abstract}
The political campaign for a Bill of Rights for Northern Ireland, which had relevance in the 1980s and 1990s, is the discordant swansong of the local human rights community. This social force originated with the Campaign on the Administration of Justice in 1981. There are four substantive arguments against the United Kingdom government doing what the Northern Ireland Human Rights Commission (NIHRC), a still unrepresentative quango, demands: (1) the draft Bill of Rights of 4 September 2001, if enacted in Northern Ireland law, would shatter human rights protection in the United Kingdom; (2) the obligation in the Belfast Agreement was to request advice on the scope for particular supplementary rights, not give the Northern Ireland Human Rights Commission carte blanche to draft a comprehensive bill of rights; (3) even if this had been in the Belfast Agreement, it would be irresponsible to scatter a cornu copia of badly formulated rights into a communally divided society with little instinct for democratic accommodation; and (4) Northern Ireland's Bill of Rights is the Human Rights Act 1998, and a framework for the future by amendment at Westminster. Arguments (1), (2) and (4) are strictly legal; argument (3) is speculative, accepting for the moment the NIHRC's false view of its remit. Human rights entered the legal mainstream across the United Kingdom on 2 October 2000. Lawyers and the judiciary now have professional human rights responsibilities. There will be a need for legal certainty. In Northern Ireland, the Committee on the Administration of Justice/Northern Ireland Human Rights Commission will be eclipsed. They are not broadly based, but they continue to be funded privately and publicly. Elected representatives in Belfast, as well as London, now have a role to play. Hopefully, the human rights of all, after the gestures and self-indulgence of the early Belfast Agreement years, will begin to be vindicated.
\end{abstract}

\section{INTRODUCTION}

I am opposed to the current proposal of a Bill of Rights (BOR) for Northern Ireland (NI). This is not because I am against human rights, a motherhood issue. As a lawyer in London and Belfast, human rights are integral to the law I practise. I have been critical of the Northern Ireland Human Rights Commission (NIHRC) since its appointment on 1 March $1999 .{ }^{2}$ This is

13 Temple Gardens, Temple, London EC4Y 9AU. info@austenmorgan.com. I would like to thank Neil Faris and Jeffrey Dudgeon for commenting helpfully on earlier drafts.

2 On 30 September 1999, the NIHRC issued a draft strategic plan for consultation. I responded to this, and the document of 13 November 1999 is available on my professional website: www.austenmorgan.com. I never expected it to have any effect. However, I was amused to find that all such responses were vetted, in 
because it has failed to contribute to the reconciling pretension of the Belfast Agreement. The draft BOR of 4 September 2001 makes no contribution to the rule of law, and to a badly needed culture of legality. The NIHRC's 155page consultation document, Making a Bill of Rights for Northern Ireland (Making) is a sloppy academic exercise. ${ }^{3}$ If implemented in the name of a greatly misunderstood international law (which is most unlikely), the NIHRC's BOR would seriously disrupt the constitutional law of the United Kingdom (UK) (and, as I shall show, the Irish) state.

Professor David Kennedy of Harvard University has recently articulated the general phenomenon of which the NIHRC is a particular instance: "The human rights community degrades the legal profession by encouraging a combination of overall formal reliance on textual articulations which are anything but clear or binding and sloppy humanitarian argument. This combination degrades the legal skills of those involved, while encouraging them to believe that their projects are more legitimate precisely because they are presented in (sloppy) legal terms."4

In this article, I look at the legal meaning of a BOR, generally and in the case of NI. This section contains background information on the Committee on the Administration of Justice (CAJ), and its BOR of 1993. I then consider four substantive arguments against the NIHRC's BOR: (1) the draft Bill of Rights of 4 September 2001, if enacted in Northern Ireland law, would shatter human rights protection in the United Kingdom; (2) the obligation in the Belfast Agreement was to request advice on the scope for particular supplementary rights, not give the NIHRC carte blanche to draft a comprehensive bill of rights; (3) even if this had been in the Belfast Agreement, it would be irresponsible to scatter a cornu copia of badly formulated rights into a communally divided society with little instinct for democratic accommodation; and (4) Northern Ireland's Bill of Rights is the Human Rights Act (HRA) 1998, and a framework for the future by amendment at Westminster. I conclude by making some practical proposals for a genuine human rights culture for all in NI.

\section{The Legal Meaning of a Bill of Rights}

There has been an important debate since the early 1990s about human rights. However, there is a clear distinction between the so-called incorporation of the European Convention on Human Rights (ECHR), and a full-blown constitutional bill of rights for the United Kingdom (which could be part of a written constitution). ${ }^{5}$ The former is part of a continental project; the latter would be unique to the United Kingdom. The Human Rights Act 1998, which entered fully into force throughout the UK on 2 October 2000, is the only legal show in town. The new Labour government re-elected in

accordance with an ideological interpretation of section 75 of the Northern Ireland Act (NIA) 1998: NIHRC minutes, 13 December 1999; 17 January 2000.

3 Appendix 1 contains what I call the draft BOR or the NIHRC's BOR.

4 "The International Human Rights Movement: part of the problem?"

[2001] EHRLR 245 at 262.

5 Robert Blackburn, Towards a Constitutional Bill of Rights for the United Kingdom (London, 1999), pp xxviii-xxix \& xxxii. 
2001 is committed to its bedding down. This remains the position as regards NI, despite the particularity of the Belfast Agreement (of which more below).

\section{What are human rights?}

Human rights is a trendy and tribal slogan in NI. As a practising lawyer, I am adverse to declaratory gestures. The only things that should matter for lawyers are practical remedies for natural and legal persons, achieved through a profession with legal duties and ethical standards. Human rights that are not legal rights remain purely an aspiration; at best a value, at worst barely disguised domestic and/or international politicking. ${ }^{6}$ If a right is not legal, enforceable and able to give rise to relief and remedies, it is something other - at best a suggested right.

The source of contemporary human rights is post-world-war-two multilateral agreements, associated principally with the United Nations and the Council of Europe. These instruments are greatly misunderstood in NI, where international law and human rights tend to be considered as identical: international human rights standards! ${ }^{7}$

Public international law (hereinafter "international law”) remains essentially the law of states, though it was once known as the law of nations. ${ }^{8}$ However, international legal personality may be bestowed on international organizations. Arguably, individuals remain the objects of international law. ${ }^{9}$ They are the beneficiaries of international humanitarian law. This has come to include human rights, which are governed by the law of treaties. Not all international documents (as the human rights community tends to suggest) have legal effect. They certainly do not become domestic law in dualist constitutions, such as the UK and the Republic of Ireland ("ROI"). Only some international agreements are, what are called, law-making treaties. So-called soft law is not, of course, binding - anywhere. International law remains largely customary, and based upon the practice of states. ${ }^{10}$ International instruments bind states parties; they are essentially of evidential value, as regards the customs and overriding principles of international law ${ }^{11}$. There is also customary international human rights law, based upon state policy. This deals with a finite number of rights, though no state claims the right to practise genocide, slavery, torture, systematic racial (including religious?) discrimination etc. ${ }^{12}$

Geoffrey Robertson QC has expressed the distinction between the culture of the human rights community and international law thus: "Many overoptimistic international lawyers argue that everything in the Universal

6 David Kennedy, "The Forgotten Politics of International Governance", "The International Human Rights Movement: part of the problem?" and "The Politics of the Invisible College: international governance and the politics of expertise" [2001] EHRLR 117, 245 \& 463.

7 See the definition of international law in Making, p 94, which misconstrues article 39(1)(b)-(c) of the South African constitution.

8 Ibid p 145 .

9 Though Hersch Lauterpacht thought otherwise.

10 See the NIHRC's misuse of this concept: Making, $\mathrm{p} 94$

11 Ian Brownlie, Principles of Public International Law, $4^{\text {th }}$ ed (Oxford 1990), p 4.

12 American Law Institute, Restatement of the Law Third, vol. 2 (1987), para 702. 
Declaration of Human Rights is by now part of international law, but this is the sort of wishful thinking that has made international human rights law such a fatuous exercise. If human rights are to have the force of law in the twenty-first century, we must abandon these norms of the imagination (which guarantee sophisticated rights to hundreds of millions of women and children who have no hope of possessing them) and concentrate on consolidating, and above all enforcing, the elemental rules which have already ripened into rules of international law."13

The 1950 European Convention for the Protection of Human Rights and Fundamental Freedoms, and the associated Commission and Court in Strasbourg (now just the Court), has been of most practical use in Europe. Its principal drafter was a retired UK official, whose inspiration was the (originally English) common law. Much is made of the so-called positive rights of multilateral agreements, but the ECHR reflects the effectively negative freedoms of the common law. ${ }^{14}$ What are now called (international) Convention rights in the HRA $1998^{15}$ retain a complex relationship with judge-made law in the $\mathrm{UK}^{16}$.

There is a great deal of ill-informed talk about international human rights standards in NI. The proper comparator for the UK's record regionally is the way other European states, bound by the ECHR, dealt - and still deal - with domestic and international terrorism. Have the solutions been proportionate to the problems? The issue then becomes: what are the human rights protected by multilateral agreements within international law, and how are they enforceable - if at all? The next question is: what is the domestic human rights law (now substituting for Strasbourg jurisdiction) within the three legal jurisdictions of the UK? Only then does the question arise on a particular right: what are the standards in international and domestic jurisprudence, and how should they be applied here to a particular case?

\section{Human rights: violations $v$ abuses}

The modern concept of human rights was a response to the conduct of mainly the German state (and its allies) in the 1930s and 1940s. States were then assumed to be the main abusers of human rights, using the term "abusers" colloquially. This was a reasonable assumption in 1950. States, of course, are the only respondents at Strasbourg, where they may be found liable for what are called violations ${ }^{17}$. Equally reasonably, at the beginning of the twenty-first century, we now know that sub-state actors may also abuse human rights extensively. I refer principally to the phenomenon of terrorism in the last quarter of the twentieth century. Terrorism may be domestic; but it is increasingly international. Abuse is a term of art in the ECHR, but it remains to be developed in accord with the "living instrument" doctrine $^{18}$ of the Strasbourg court. After 11 September (a day infamous in

13 Crimes against Humanity (London 2000), pp 81-2.

14 Peter Duffy QC \& Paul Stanley, annotators of the HRA 1998, Current Law Statutes, vol 3, 1999, p 42.

$15 \mathrm{~S} \mathrm{1(1).}$

16 Derbyshire County Council v Times Newspapers [1993] AC 534, 551 per Lord Keith of Kinkel.

17 ECHR, art 34.

18 Tyrer $\mathrm{v}$ UK (1978) 2 EHRR, 1 at 10. 
history), we now accept that such terrorists may be organized internationally, and may use one state as a platform for the equivalent of acts of war against another state.

The problem of terrorism has been experienced among Council of Europe member states most intensively in NI by the UK (which is not to underestimate the internal security threats experienced by France, Germany, Italy and especially Spain, in the 1970s and 1980s, and still continuing). There is now something called Irish terrorism in the UK. ${ }^{19}$ Victims of terrorism had no recourse to Strasbourg, other than against a state party for inadequate protection. With the so-called incorporation of the ECHR in UK law, it may well be possible for such persons (or their relatives), by suing paramilitaries, to develop the indirect horizontal effect in the HRA 1998, to secure relief and remedies in NI courts. ${ }^{20}$

I alerted the NIHRC to this exciting possibility early in its existence. ${ }^{21}$ The indirect horizontal effect is the principal significance regionally, of the shift on 2 October 2000 from Strasbourg and the ECHR to domestic courts and the HRA 1998. The NIHRC has continued to rail against state violations, and effectively ignore paramilitary and other abuses. And this in spite of $H L R$ v France, ${ }^{22}$ where Strasbourg held (though it rejected the application of a Columbian drug trafficker against deportation) that the source of the risk could be the threat of reprisals by drug traffickers, coupled with the fact that the Columbian State is allegedly incapable of protecting him from attacks by such persons.

\section{International refugee law}

An analogy may be drawn between refugee law and human rights law; both are aspects of international humanitarian law. The former derives in the main from the 1951 Geneva Convention and a 1967 Protocol. It is, therefore, law based upon a multilateral international agreement. This has not been incorporated in UK law, but it is referred to in statutes and other domestic instruments. Immigration law is a major aspect of the public law of, principally, England and Wales. Applicants for asylum may appeal to special courts, against decisions of the Secretary of State. Practitioners in the Independent Appellate Authority apply the law of asylum - a well-founded

19 This originated in the definition of terrorism as connected with the affairs of NI Lord Lloyd of Berwick's Inquiry into Legislation against Terrorism, Cm 3420 , October 1996, argued for a tripartite distinction: Irish, international and domestic. This was accepted by the government: Legislation against Terrorism, Cm 4178 , December 1998. The Terrorism Act 2000 applies to Irish, international and domestic terrorism. It is not known if the Republic of Ireland objected to the term Irish terrorism after 1996. None of the terms is defined in the Terrorism Act 2000.

20 HRA 1998, ss 6(3) \& 7(1)(b); Murray Hunt, “' "The Horizontal Effect' of the Human Rights Act" [1998] PL 423; Thomas Raphael, "The Problem of Horizontal Effect" [2000] EHRLR 493; Ralf Brinktrine, "The Horizontal Effect of Human Rights in German Constitutional Law" [2001] EHRLR 421; Ivan Hare, "Vertically Challenged: private parties, privacy and the Human Rights Act", [2001] EHRLR 526.

21 See note 1 above.

22 (1997) 26 EHRR 29. 
fear of persecution for, what is called, a Convention reason - using international and domestic jurisprudence.

In 1951, the assumption was that only states persecuted those who fled in fear. We now know differently. International refugee law, or UK immigration law to be more precise, now recognizes what it calls non-state agents.

In Horvath v Secretary of State for the Home Department, ${ }^{23}$ the House of Lords held: given that the general purpose of the refugee convention was provision by the international community of surrogate protection, the test of whether ill-treatment amounted to persecution was dependent upon, not only the severity of the ill-treatment, but also upon there being a failure by the state to afford protection against the ill-treatment. The Appellate Committee did not blame "the state" for the putative persecution by non-state agents. However, it insisted that the authorities should be able to deal with the consequences: there is a per curiam that the standard is a system of criminal law which makes violent attacks by the persecutors punishable and a reasonable willingness to enforce that law on the part of the law enforcement agents.

This case - contra the human rights community in NI (and their acolytes in Great Britain and the Republic of Ireland) - recognizes the victims of substate agents. The persecution flows in part from the latter. It is not exclusively a matter of inadequate protection by "the state", as the supporters of the NIHRC continue to insist. This argument by analogy has been accepted by the Immigration Appeal Tribunal, in the starred decision, Kacaj, of 19 July 2001.

\section{The particularity of Northern Ireland}

The greatest abusers of human rights in NI in the 30 years of the troubles contrary to the impression given by the NIHRC - were, not the police and the army, but republican and loyalist terrorists. According to the Costs of the Troubles Study at the University of Ulster, for the period 1969 to seemingly the end of February 1998, some 3,593 people were recorded as having been killed in political violence. The largest category is people killed by republican paramilitaries: 2,001 or 56 per cent. The second largest is killings perpetrated by loyalist paramilitaries: 983 deaths or 27 per cent. The security forces combined were responsible for 382 deaths or 11 per cent. ${ }^{24}$ It is therefore the position that the vast majority of deaths - at least 83 per cent are attributable to illegal paramilitary organizations; just over one in ten was the responsibility of what the human rights community calls "the state". Not all of the latter would have been as a result of force that was no more than absolutely necessary. ${ }^{25}$ Almost all (if not all) of the former will have amounted to the abuse of the right to life under article 2 of the ECHR.

23 [2000] 3 WLR 379.

24 Marie-Therese Fay, Mike Morrisey \& Marie Smyth, Northern Ireland's Troubles (London 1999), p 170. The human rights community is concerned principally with the latter category: Fionnuala Ní Aoláin, The Politics of Force (Belfast 2000).

25 There is no Strasbourg case finding the UK liable for a substantive breach of art 2 in NI. McCann v UK (1996) 21 EHRR 97 concerned Gibraltar (a substantive breach by ten votes to nine). The Jordan, McKerr, Kelly \& Others, and Shanighan 


\section{A bill of rights?}

There is, of course, a bill of rights in the UK, of 1688-89. It is an important part of the uncodified constitution. And it is still litigated.

However, it was in November 1968 that Anthony Lester made his first call for the incorporation of the ECHR in domestic UK law, in his Fabian pamphlet, Democracy and Individual Rights. The term incorporation has stuck, and may be used colloquially. Strictly, incorporation refers to customary rules of international law having domestic effect. Transformation ${ }^{26}$ would have been a better term for a multilateral agreement in international law. Recognition should also be given C. Desmond Greaves, in the context of the NI civil rights movement. He argued on behalf of the Connolly Association in London, that Westminster should legislate for the province. ${ }^{27}$ This was part of a democratic solution, inspired by socialism but mainly by nationalism.

A regional bill of rights was suggested by the Ulster Unionist Party (UUP), the Alliance Party and the Northern Ireland Labour Party in October 1972. This was in the Northern Ireland Office (NIO) document, The Future of Northern Ireland: a paper for discussion. Nationalists did not join in these calls, ${ }^{28}$ which were made shortly after the fall of Stormont. (There had, of course, been a provision against religious discrimination in section 5 of the Government of Ireland Act 1920.) The UK posed, by way of comment, the question of human rights abuses by terrorists. ${ }^{29}$ A subsequent white paper ${ }^{30}$ hinted at a (unenforceable) charter of human rights. In the Northern Ireland Constitution Act 1973, part III on the prevention of religious and political discrimination prohibited such acts by public authorities. A Standing Advisory Commission on Human Rights (SACHR) was also established. Though its remit was discrimination, it was SACHR which advised in 1977 with the help of Anthony Lester - that there should be a bill of rights. ${ }^{31}$ The proposal amounted to the incorporation of the ECHR. This was to be UK wide, though Robert Cooper (dissenting) favoured a NI bill rather than wait for Great Britain to catch up.

A UK bill of rights then, as advocated in the 1970s, meant the ECHR. This was the sense in which the NI political parties would refer subsequently to the proposal. And a bill of rights was not antipathetic to the majority community, from where unionism draws its support principally. The answer given invariably, when nationalists and others pressed catholic grievances, was: continued involvement in the UK, with a bill of rights as one of the benefits and a principal safeguard for minorities and individuals.

decisions of 4 May 2001 relate only to a procedural breach (seven votes unanimously).

26 Confer transposition of European Community/Union law.

27 The Irish Crisis (London 1972), pp 197-88, 200, 204 \& 217; Bob Purdie, Politics in the Street (Belfast 1990), p 112.

28 For a later assessment, see chapter 4 of the CAJ's Making Rights Count (1990).

29 Paras 27-32 \& 64.

30 Northern Ireland Constitutional Proposals, Cmnd 5259, March 1973, part IV.

31 The Protection of Human Rights by Law in Northern Ireland, Cmnd 7009, November 1977. 
However, the matter was to rest for over 20 years, following the publication of the SACHR report. The UK was opposed in the 1980s and 1990s to the incorporation of the ECHR. So also was the Republic of Ireland, which was content with its fundamental rights in Bunreacht na hÉireann (articles 40 to 44). In the concerted attempt from the late 1980s to settle the NI problem, London and Dublin jointly eschewed any commitment to ECHR incorporation. $^{32}$ It was suggested in 1995 that democratic representatives might adopt instead a (non binding) all-Ireland charter or covenant. ${ }^{33}$ The UK idea of a non-binding charter of 1973 for NI became, 22 years later, the Irish idea of an all-Ireland charter.

The significance of the Belfast Agreement, from the point of view of human rights protection, was the way the UUP, drawing on new Labour's commitment to the ECHR (see below), forced the Irish state to agree to an equivalent level of protection of human rights with the UK. ${ }^{34}$

What Anthony Lester initiated in 1968 would take 30 years to be realized as the HRA 1998. A whole series of legal factors contributed to this process. ${ }^{35}$ NI's contribution was the troubles. There were also adverse human rights decisions against the UK at Strasbourg. New Labour (but only in GB) inspired by the Institute of Public Policy Research ${ }^{36}$ and Liberty ${ }^{37}$ embraced the ECHR in 1993. ${ }^{38}$ There followed the 1996 consultation paper, Bringing Rights Home, ${ }^{39}$ which led - following the election of the Blair government - to the October 1997 white paper, Rights Brought Home. ${ }^{40}$

\section{The Committee on the Administration of Justice (CAJ)}

The above narrative is broadly complete. But it leaves out an important subcurrent, the CAJ founded in Belfast in 1981. And it is not possible to understand the NIHRC individually and ideologically, without reference to

32 Downing Street Declaration, Cmnd 2442, 15 December 1993; Framework Documents, Cmnd 2964, February 1995.

33 In the 1995 Framework Documents. This was to be based apparently upon the six so-called rights included in the 1993 Downing Street Declaration. See further, Austen Morgan, The Belfast Agreement: a practical legal analysis (London 2000), pp 373-4 \& 375-6.

34 First paragraph 9 of the Rights, Safeguards and Equality of Opportunity section.

35 I list them in Austen Morgan, The Belfast Agreement: a practical legal analysis (London 2000), pp 361-2.

36 A British Bill of Rights (1990), included subsequently in The Constitution of the $U K$ (1991). It was based upon the ECHR, with additions from the 1966 International Covenant on Civil and Political Rights. It was published again, as $A$ Written Constitution for the UK (1993).

37 National Council for Civil Liberties, A People's Charter (1991). This referred to "the UK Bill of Rights". It was also based upon the ECHR and the 1966 international civil and political rights covenant.

38 The party conference that year agreed: one, incorporation of the ECHR; two, an all-party commission to consider and draft a homegrown bill of rights for the UK.

3918 December, published in [1997] EHRLR 71. This was the only UK document to refer to a BOR for NI: "a distinct package of rights as part of a new agreed and balanced settlement for Northern Ireland." However, it was looking back to the 1977 SACHR report, and the human rights bill had not then even been drafted.

$40 \mathrm{Cm} 3782$. There is a reference to NI in para 2.23 . 
this controversial pressure group. Indeed, the precedent for the draft BOR of 2001 is the CAJ's bill of rights of $1993^{41}$.

The CAJ styles itself a non-governmental organization (NGO in the argot of diplomacy), but is not state wide. It would claim to take no position on the constitutional question, to be effectively neutral in NI. Neutrality here means: a refusal to accept NI's constitutional position in the UK (including especially the legitimate use of force); and an acceptance of a united Ireland as a viable alternative (diminishing its criticism of republican violence). ${ }^{42}$ The CAJ did not anticipate, and has not followed, the "consent" principle of the Belfast Agreement, a constitutional provision that may be traced from $1922^{43}$. As for its opposition to violence, it has used "international law" to justify its non-criticism of the main human rights abusers. ${ }^{44}$

The CAJ can only be understood against a background of post-war social and political changes in the UK, and particularly the effects of the "class of ' 68 " on culture and learning: the transcendence of liberalism by fundamentalist identity politics. These thrived in the NI troubles. In metropolitan Britain, in contrast, they were confronted by Margaret Thatcher, and transformed by new Labour. The Greater London Council under Ken Livingstone is a warning from history. In the 1980s and, especially after the fall of the Berlin wall in 1989, "human rights" was to become a provincial Manichean cause, in communion with Irish nationalism, and substantially replacing extraparliamentary socialism. NI is noted for historical survivals, long after the passing of the conditions elsewhere which gave rise to them.

Steve McBride, one of the human rights pioneers, recalled of 1981: "when we set up the CAJ, there was a major recognition that what was needed was an independent, objective, organization which would take an honest, nonpartisan stand on issues of human rights in the North.” By 1995, as justice spokesman for the Alliance Party, this former chairman had to admit: "I must say that there are some aspects of the CAJ. . . which I would have to say I am frankly disappointed with. ... Do they recognize that the greatest abuse of

41 Bill of Rights for Northern Ireland. See also, The Blessings of Liberty (1986) and Making Rights Count (1990), which contains an earlier draft of the BOR.

42 A good analogy is James Connolly's so-called neutrality in 1914, a prelude to theoretical and practical pro-Germanism: Austen Morgan, James Connolly (Manchester 1988) pp 150-1.

43 Austen Morgan, The Belfast Agreement: a practical legal analysis (London 2000), pp 134-49. The Belfast Agreement did not alter NI's position in the UK. The Republic Of Ireland, in contrast, ended its territorial claim. Aspirations remain legitimate, and further effect was given to unity by consent.

44 "We have set ourselves up as a non-governmental organization to comment on how the State deals with non-State violence. . . You may not like it but it is our function. . . We are simply abstracting ourselves from the local situation and applying international law." (Michael Ritchie, Forum for Peace and Reconciliation, Report of Proceedings: volume 12: Friday, 31 March 1995, pp 445) See also, Brice Dickson, "The Protection of Human Rights: Lessons from Northern Ireland" [2000] EHRLR 213 at 222 (equating state violence with paramilitary violence in the context of the NIHRC's definition of victim). 
human rights in Northern Ireland in the last twenty five years is that carried out by paramilitary groups. . ."45.

The answer to Steve McBride's question is, of course, no. This is evident from the public session of the Irish government's Forum for Peace and Reconciliation in Dublin Castle on 31 March 1995, when the CAJ (and its sister organization, the Irish Council for Civil Liberties [ICCL]) made a joint presentation to members ${ }^{46}$, comprising nationalist and other political leaders but no unionists. Elected politicians - including Dr John (now Lord) Alderdice of the Alliance Party (and now speaker of the NI Assembly), Mary Harney TD (leader of the Progressive Democrats and now tánaiste) and Michael McDowell TD (of the same party and now Irish attorney general) criticized severely what was becoming a radical community in both parts of Ireland, using human rights to promote a political project with a considerable vanguard role for itself.

The hauteur of this self-appointed elite, and its disdain for what ordinary people believe to be human rights (whether drawing on religious consciousness or secular values), is remarkable. ${ }^{47}$

\section{The CAJ's Bill of Rights for Northern Ireland (1993)}

Strangely, this was a bill only for Northern Ireland, at a time when civil liberties organizations in Great Britain were putting forward proposals for the UK as a whole. What explains the CAJ's isolation? The answer is its relationship to nationalism, reflected in its purported constitutional neutrality. The preamble began: "However Northern Ireland is governed". Why the doubt? The commentary read: "The CAJ intends this Bill of Rights to apply whatever the constitutional arrangements are in place at any particular time for governing the area known as Northern Ireland. The organisation takes no position on what the constitutional status of Northern

45 Forum for Peace and Reconciliation, Report of Proceedings: volume 12: Friday, 31 March 1995, pp 26-7.

46 Angela Hegarty, Anne McKeown and Michael Ritchie represented the CAJ; Tom Cooney, Michael Farrell and Úna ní Raifeartaigh represented the ICCL.

47 "Clearly we need to have another go at restating our position on the question of non-State violence. We have said that we are opposed to it. Clearly that is not adequate for many people. Unfortunately that may be a matter of the lack of a human rights environment that we have." (Michael Ritchie, Forum for Peace and Reconciliation, Report of Proceedings: volume 12: Friday, 31 March 1995, p 44); see also, "Something we have noticed in our work already, even though the Human Rights Act is in its infancy, is that ordinary people, and others, are ignorant about human rights. Many people, including some politicians, are confused about how human rights apply, thinking that the rights protected by the Human Rights Act can regulate disputes between citizens, rather than between citizens and public authorities. Education is clearly needed to dispel this confusion, otherwise there is a danger that people will feel let down by the Act because of erroneous perceptions about its scope." (Jane Winter, letter, 26 February 2001, to chairman Joint Committee on Human Rights, 2000-01, Second Special Report: implementation of the Human Rights Act 1998, HL Paper 66-I/HC 332-I, volume II, p 27) Both the CAJ and British Irish Rights Watch have been singled out for praise by Prof Brice Dickson of the NIHRC: 'The Protection of Human Rights: lessons from Northern Ireland', Paul Sieghart memorial lecture 2000, p 13. 
Ireland should be." 48 The identification of a BOR with a territory only is legally problematic, and compounded by an effective denial of UK sovereignty which is not legally balanced by an apparent disavowal of Irish sovereignty.

CAJ members drafted this BOR, mainly: Christine Bell, Brice Dickson, Donall Murphy, Martin O'Brien and Fionnuala Ní Aoláin. The first two were to become members of the NIHRC in 1999, Brice Dickson becoming the Chief Commissioner. The fourth is the CAJ's director. And the fifth is a member of the Irish Human Rights Commission (Irish HRC), set up belatedly under the Belfast Agreement in the Republic of Ireland.

The CAJ's BOR had 20 articles, and was at the time an important local contribution. The following points may be made.

One, it drew widely on human rights instruments and even constitutions. Two, there were no limitations in individual articles, but cross-references to a general limitation: (a) absolutely necessary, (b) prescribed by law and (c) manifestly justifiable in a free and democratic society. Three, it was concerned only with human rights violations. Four, it confused the distinction between international law and domestic law (apparently looking at "the [British] state" from within the Irish nation). Five, it included economic, social and cultural rights, and, separately, group rights (though these seemed to relate to class actions only). Six, and strangely, no reference was made to Westminster enactment: "The CAJ does not hold a collective view on precisely how the Bill of Rights should be made a part of the law of Northern Ireland." 49 A proposal for amendment by two thirds of those voting in a referendum in NI, failed to appreciate that, under the doctrine of parliamentary sovereignty, referendums can only be consultative. ${ }^{50}$

\section{The NIHRC's campaign}

The NIHRC focussed early upon the BOR project. As the end of their three year appointments approached (and before their reappointment), Professor Dickson and his fellow commissioners became more frantic to achieve the CAJ's objective. ${ }^{51}$ This campaign at public expense was marked by the following highlights:

- 1 March 2000: publication of the pamphlet, A New Bill of Rights for Northern Ireland, ${ }^{52}$ at the launch of the NIHRC's consultation;

48 This phrase, of course, reappears on $\mathrm{p} 19$ of Making.

49 There was, however, a reference to an ordinary Act of Parliament in the commentary on article 20.

50 See, for example, para 2 of the Validation, Implementation and Review section of the Belfast Agreement.

51 NIHRC minutes, 10 September 2001.

52 This paraphrased the first paragraph 4 of the Rights, Safeguards and Equality of Opportunity section of the Belfast Agreement to read: "consulting and advising on the scope for defining rights additional to those in the European Convention on Human Rights". It also claimed: "Under the Good Friday Agreement the [NIHRC] has been given the job of preparing a Bill of Rights for Northern Ireland." 
- September 2000: publication of 11 NIHRC pamphlets on aspects of a BOR $^{53}$;

- 15 January 2001: publication of the conclusions of nine working groups on the same areas; ${ }^{54}$

- 4 September 2001: NIHRC submits its draft BOR to the UK government, and launches a short consultation (ending on 1 December 2001), to be followed presumably by a redrafted BOR; $; 5$

- collaboration with an ad-hoc Human Rights Consortium, in which the CAJ played a major role ${ }^{56}$, including the production of a joint Belfast Telegraph supplement, Right here Write now: making a bill of rights for Northern Ireland ${ }^{57}$ and other advertising.

Professor Dickson, and the NIHRC, persisted in giving the false impression that every political party in NI supported the BOR. ${ }^{58}$

On 25 September 2001 (as was foreseeable), a motion in the NI Assembly originating with two liberal unionists, condemned the NIHRC. ${ }^{59}$ When the nationalist Social Democratic \& Labour Party (SDLP) organized a petition of concern, the motion secured a majority (48 to 39), but not a cross community, vote a week later. ${ }^{60}$ It was subsequently inevitable that the NIHRC's BOR would not secure necessary political support.

53 One on women was announced for November 2000, but delayed to at least February 2001. The titles are: Introduction; Children \& Young People; Criminal Justice; Culture \& Identity; Education; Equality; Language; Social \& Economic Rights; Victims; Women; Implementation.

54 These were on: Children \& Young People; Criminal Justice; Culture \& Identity; Education; Equality; Language; Economic \& Social Rights; Victims; and Implementation. There was nothing on Women. These (with the exception of Language, Equality and Implementation) made no reference to the Belfast Agreement provisions. The conclusions on Criminal Justice rewrote article 5 of the ECHR. That on Culture \& Identity recommended the incorporation of the Framework Convention on the Protection of National Minorities, contrary to the intention of the contracting states.

55 Making. The original intention had been to publish draft proposals in March 2001 and submit final recommendations in September 2001 (NIHRC, The Bill of Rights: Introduction, September 2000, p 8). The NIHRC envisaged Making as "draft advice" to be sent to the Secretary of State (Minutes, 14 May 2001). A NIHRC press release of 4 September 2001 referred to "preliminary advice to the Secretary of State", and to "final advice for the Secretary of State early in 2002". Professor Dickson referred to "provisional recommendations to the Secretary of State" on 4 September 2001, but also to consultation (supplied text)

56 The first telephone number of the Consortium is the CAJ's; the second is Amnesty International in Belfast

57 This was distributed in November 2001.

58 NIHRC press releases, 1 March 2000 \& 17 October 2000. For a belated qualification of this claim, see Making, p 6; www.utvinternet.com for 4 September 2001; Belfast Telegraph, 4 September 2001. The former position is reasserted in the undated Belfast Telegraph supplement, $\mathrm{p} 2$.

59 Northern Ireland Assembly, Official Report, vol 12, no 6, 25 September 2001, pp 199-214.

60 Northern Ireland Assembly, Official Report, vol 12, no 7, 1 October 2001, p 262. 


\section{The NIHRC's BOR}

The consultation document Making is significant principally for its length. It contains as appendix 1 the 164 draft clauses in 24 pages. Presumably, this is the basis for a Westminster statute. (This is the text I discuss subsequently, referring to the commentary only when necessary.) Of the 164 clauses, only 37 have existing domestic legal effect, through the HRA 1998. Seventy seven per cent of the NIHRC's BOR is therefore new. It makes the CAJ's BOR of 1993 a modest proposal in comparison.

The structure of the BOR is: a preamble followed by 18 other numbered chapters, each containing several clauses. ${ }^{\mathbf{1}}$ The ECHR (including protocol articles which are now Convention rights under the HRA 1998) appears to be the basis of the document. However, the Convention rights are grouped in

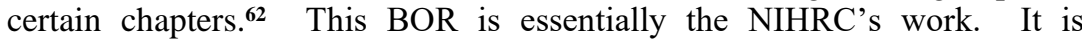
responsible for most of the chapters, and (as noted) the vast majority of the clauses. The chapters range far beyond civil and political rights, and even economic, social and cultural ones. Included are: electoral rights, identity and communities, women (though there are no actual rights in this chapter); victims; children; education; and language. Most of these are topics dealt with normally by representatives in legislatures, elected on the basis of political programmes. The NIHRC's BOR eclipses in scale those of: France (1789); the United States (1791); Germany (1949), various Caribbean states (1962-81), Canada (1982), New Zealand (1990), Hong Kong (1991), and South Africa (1996). ${ }^{63}$ Each one of those bills of rights was created in a particular historical conjuncture. Not one is analogous to NI in 2001-02. They may be looked at for drafting purposes, but none is a precedent for a NI where the Belfast Agreement did not include provision for a NIHRC BOR (see further below).

The Belfast Agreement was the work of the political parties of NI in 199698 , under the guidance of the two governments. The NIHRC, judging by appendix 5, seems not to understand what sort of legal instrument it is. ${ }^{64}$ This would-be BOR is a document of almost equal stature. However, an unrepresentative human rights community ${ }^{\mathbf{6 5}}$, which is the beneficiary of NIO patronage, has produced it. It was also facilitated by an extraordinary amount of public money. Having declined repeated NIHRC requests for more funds, the NIO relented and gave $£ 357,200$ to conduct a consultation exercise. This would appear to be one of the most expensive consultations in the history of the UK state. One looks forward to the NIHRC being held to account financially by London.

61 This suggests that the drafter does not understand the status of a preamble. Moreover, we are given here the preamble of an international agreement, not domestic legislation.

${ }^{62}$ For example, articles 2, 3 and 4 in chapter 6, articles 5, 6 and 7 in chapter 7, articles 8 and 12 in chapter 9 , and articles 9,10 and 11 in chapter 12 (where there is an attempt to play down freedom of peaceful assembly).

63 Robert Blackburn, Towards a Constitutional Bill of Rights for the United Kingdom (London 1999), pp 443-529.

64 It is listed under "Domestic standards and references".

65 See my submission of 13 November 1999: www.austenmorgan.com. 
The preamble of the bill is framed: "The people of Northern Ireland. . . have requested the adoption of the following Bill of Rights." What people? Is this the real people of NI, in their divided unity? Or is it the obedient people of revolutionary mythology? It certainly does not include people "of a certain kind" - those opposed to some or all of the BOR ${ }^{66}$. Popular demand is difficult to resist. And the NIHRC is clearly attempting to appeal over the heads of elected representatives. There was a fantasy in the NIHRC about popular pressure producing a cross-community vote of the Assembly. ${ }^{67}$ Fortunately, as noted above, this has not, and will not, succeed. The BOR is a political initiative of stunning audacity, for a statutory body (or quango) of less than three years' existence. The NIHRC was not set up to mobilize the people, and short circuit the NI Assembly, to press demands upon, not just the UK government, but also (as I shall show) the Irish government. Its functions were laid down in the Northern Ireland Act 1998 ("NIA 1998"), on the basis of the first paragraph 5 of the Rights, Safeguards and Equality of Opportunity section of the Belfast Agreement.

I am concerned with the overall context of the Belfast Agreement, and UK (and Irish) law. The sheer scale of the BOR has major constitutional, as well as, most obviously, political, significance.

\section{FOUR ARGUMENTS AGAINST}

There are four principal arguments against the NIHRC's draft BOR. Points are, of course, interrelated, but my case is presented as four discrete legal submissions. If it is political to campaign for a BOR, one becomes involved in political debate by opposing the NIHRC's grandiose plan. Argument (3) is an attempt to engage with any rational wing of the human rights community. It takes a constitutional stand in favour of elected politicians, and against a veritable fourth branch of government (as the NIHRC conducts itself ${ }^{68}$, making policy decisions on behalf of the people.

\section{(1) The draft BOR of 4 September 2001, if enacted in NI law, would shatter human rights protection in the UK}

This argument is concerned with the human rights protection provided in the UK by the HRA 1998. I contend that the NIHRC's BOR would separate NI from Great Britain in this respect. Further, and even more worryingly, it would undermine many rules of statutory, but mainly common, law. I do not envisage parliamentary counsel in London starting with the NIHRC's BOR, and amending every necessary rule in order to have an extensive human rights regime uniquely in NI. Incredibly, there is no reference to the HRA 1998 in appendix 1 of Making. Nor is there any serious discussion of existing human rights law in the commentary. ${ }^{69}$ There is very little acknowledgement of Westminster legislation, though Professor Kevin Boyle gave the game away on 4 September 2001, at the launch of the draft BOR, by

66 A phrase coined by Gerry Adams, but inspired by Brendan O'Leary (with reference to reverse discrimination in favour of Catholics including political vetting): Irish Independent, 2 November 1999; Irish Times, 14 June 2001.

67 Making, p 18.

68 See my article in the Observer, 19 August 2001.

69 See pp 59, 87, 100,102,103, 138 \& 144; it is not referred to on $\mathrm{p} 149$. 
referring to "entrench[ing] by law when the Westminster Parliament ultimately legislates Northern Ireland's Bill of Rights."

The following points all arise from the draft BOR. They are not simply technical. They go to the heart of the NIHRC's legal competence.

\section{(i) Northern Ireland: states and nations?}

There is complete legal continuity between the CAJ in 1993 and the NIHRC in 2001. Reference has been made above to the constitutional perspective of the first Bill of Rights for Northern Ireland. The CAJ was confused about states and nations. After the Belfast Agreement, there is less reason for the NIHRC reproducing the CAJ idea of a NI territory with its own BOR, effectively in movement between the UK and the Republic of Ireland.

The drafter of the NIHRC's BOR treats NI as constitutionally autonomous (less a part of the UK and more a part of the Irish nation ${ }^{71}$ ). Thus, the strange analogy on page 107 of Making with the 1931 Statute of Westminster. This concerned relations between states, in the transition from empire to commonwealth. It has no application to NI's position within the UK, a unitary state that has devolved power to its regions and nations.

The second aspect of this legal continuity is the view that NI, while - sotto voce - a part of the UK, has a destiny in an all-Ireland state. This reflects more a transition to a united Ireland view (characteristic of Sinn Féin), than a joint sovereignty, or authority, view, sometimes associated with the SDLP and the Irish government. Thus, on pages 18 to 19 of Making, there is an oblique reference to article 1 of the British-Irish Agreement, in particular paragraphs (v) and (vi). ${ }^{72}$ The identities of Irish or British (acknowledged in the Belfast Agreement) do not justify what the NIHRC has done: namely, drafted a BOR for a NI which is, currently, in the UK, but could, just as reasonably, be a part of the Republic of Ireland. Many of the legal difficulties in the text stem from this old CAJ prejudice. It is also to misconstrue the Belfast Agreement, which is very clear about NI being a part of the UK. Virtually no attention has been paid to the second paragraph 4 of Strand Three: "There will be no derogation from the sovereignty of either Government (sic)." Further, article 1(i) of the British-Irish Agreement recognizes the legitimacy of the choice of a majority of the people of Northern Ireland with regard to its status.

70 Supplied text. The NIHRC referred bizarrely to "enact[ing] any necessary legislation as quickly as possible." (Press statement, 4 September 2001.)

71 Nation is treated uncritically as a legal category: Making, pp 144-5.

72 The phrase "The Commission, of course, holds no views on what the future constitutional status of Northern Ireland should be." repeats that in the CAJ's 1993 BOR. Does the NIHRC have a view of the current constitutional position? Does it accept that the Belfast Agreement provides further for unity by consent? If so, the only possible future constitutional status is a united Ireland. The improbability of that corresponds neatly with the legal imperative of dealing with the constitutional present of NI, and not a hybrid or halfway house. 


\section{(ii) The relationship between international law and domestic law}

This is confused in the draft BOR. While article 56 of the ECHR (territorial application) allowed London to extend the geographical scope of its international obligations, there is no concept in international law of intrastate differences (unless expressly or impliedly agreed?). However, the NIHRC envisages in domestic law: the HRA 1998 continuing to apply in GB; and, after the repeal of section 22(6), having the ECHR incorporated in NI law (in a different way from the rest of the UK). This could potentially fracture the UK's international obligations. To the argument that NI would have higher standards than Great Britain (the minimum), there is the reply that it would rapidly get out of synchronization and could fall below particular standards. ${ }^{73}$ The NIHRC's BOR would also, obviously, separate NI from Great Britain. I discount the NIHRC wanting consciously to extend its BOR to Great Britain, having the HRA 1998 repealed in its entirety and the ECHR incorporated there on the same basis as in NI.

\section{(iii) Derogations and reservations}

The confusion between international law and domestic law is evident also in chapter 17 , dealing with derogations. There is no specific reference to reservations (needless to say, denunciation - article 58 - is not recognized). Derogations and reservations are procedures in the law of treaties. These are provided for in, respectively, articles 15 and 57 of the ECHR. Because the HRA 1998 did not incorporate the ECHR strictly, the Convention rights remain in the multilateral agreement. It is therefore possible to derogate, and, in the case of new articles, make reservations (or denounce the ECHR with notice, and become a state party again with new reservations). This is under international rules on derogations and reservations. The HRA 1998, in sections 14 to 17 , makes related domestic provisions. Once the ECHR is incorporated in NI law as the NIHRC envisages, it will not be possible to derogate (or, where relevant, make reservations). A domesticated instrument can only be amended under the rules of statutory amendment, partly provided for in the instrument.

The inclusion of article 15 of the ECHR (which is not a Convention right) in the draft BOR is nonsensical. Other ECHR articles incorporated peculiarly are: 14, 16 and 17, and articles 2 and 3 of the first protocol. These relate only to the international instrument. They have no effect, or meaning, in domestic law. Interestingly, there is a reservation attached to article 2 of the first protocol and dating from 1952. This is missing entirely from the draft BOR. Does the UK have a reservation in Great Britain but not in NI?

\section{(iv) The extent of the BOR?}

The NIHRC may believe it is providing only for NI (even if it is floating between the UK and the Republic of Ireland). However, clause 14(a)(1), dealing with social, economic and cultural rights, includes the following: "All public bodies through which any of the legislative, executive or judicial powers of the State are exercised in Northern Ireland. . . shall therefore take

73 Art 11 is one example. 
legislative and/or other measures to develop and enforce programmatic responses to the social and economic rights set out below."

This must include the UK Parliament (legislative), the central government (executive) and the most senior judiciary (judicial) - all of which are located in London, from where the unitary state is still governed despite devolution to Scotland, Wales and Northern Ireland. The NIHRC tries to avoid this issue by referring parenthetically to the NI Assembly and the executive, but these are specified as "in particular". The BOR, certainly as regards social, economic and cultural rights, would have to apply in Great Britain (but only as regards NI?). Robin Cook, Tony Blair and Lord Irvine of Lairg would, therefore, have to have one set of policies for Great Britain, and another governed by the BOR - for NI. I discount the NIHRC trying to influence central government economic and social policy in general, by circumscribing 'Blairite' economic liberalization with a legalistic affirmation of economic and social ideas from the third quarter of the twentieth century.

\section{(v) States of emergency?}

Chapter 17 is headed "Emergencies", and clause 17(b) deals with "States of emergencies". This is legal nonsense. There is no such concept in United Kingdom law. There is the Emergency Powers Act (Northern Ireland) 1926, and similar legislation in Great Britain. This was passed during the general strike. It refers to interference with the supply and distribution of food, water, fuel or light, or with the means of locomotion. It is, in any case, a reserved matter, under the NIA $1998 .{ }^{74}$ This, however, is not what the NIHRC means by a state of emergency.

It is referring to the recent past of so-called emergency, or temporary, legislation. The permanent Terrorism Act 2000 has now replaced this (though section 2 and schedule 1 provide for temporary extension). The Northern Ireland Assembly does not have a devolved responsibility in this regard. And central government does not operate with a state of emergency concept. No state of emergency was declared after 11 September.

Most probably, the NIHRC is again confusing international and domestic law. Article 15 of the ECHR, which deals with derogations, specifies these as permissible in time of war or other public emergency. Public emergency is a concept of this multilateral agreement in international law. It does not necessarily require, or follow from, a declaration of a state of emergency in domestic law. Since 11 September, the United Kingdom state has sought to derogate from article 5(1) as a result of the Anti-terrorism, Crime and Security Bill being introduced in Parliament, with a section 19 statement by the Secretary of State about compatibility with Convention rights. ${ }^{75}$

It should not need stating, but it does, given the NIHRC's equal treatment of the United Kingdom and the Republic of Ireland, that a NI administration,

74 Para 14 of sch 3.

75 The Bill was published on 13 November 2001, with the Secretary of State's statement of compatibility. Also, on that day, the Human Rights Act 1998 (Designated Derogation) Order 2001, SI 2001/3644 came into force. This referred to a proposed UK derogation. 
already provided for in Bunreacht na hÉireann ${ }^{76}$, would never be allowed to exercise state of emergency powers. These are reserved for central government in the Irish constitution. ${ }^{77}$ I discount, though the NIHRC may not, major amendments to Bunreacht na hÉireann.

\section{(vi) Entrenchment?}

This was an important issue in the early 1990s. It has been superseded in the main by the HRA 1998. This recognizes the continuing centrality of the doctrine of parliamentary sovereignty. ${ }^{78}$ However, the NIHRC is still seeking to realize the CAJ's plan of 1993.

Clause 19(1) (there is no 19(2)!) effectively makes the Northern Ireland Assembly a house of Parliament, at least as regards a regional BOR. The origin of this idea lies in academic speculation about the so-called constitutional guarantee about NI's position within the United Kingdom. ${ }^{79}$ It did not work in that context, and it does not work here. Parliament would never envisage such an arrangement. The Northern Ireland Assembly has been devolved, it has also been suspended, and it could be prorogued and/or abolished (as happened to the former NI Parliament). Human rights, in any case, is an excepted matter under the NIA 1998, and is a matter exclusively for Westminster. ${ }^{\mathbf{8 0}}$

Again, it should not need stating, but it does, given the NIHRC's equal treatment of the United Kingdom and Republic of Ireland, that a Northern Ireland Assembly could not have such a role under Bunreacht na hÉireann. Human rights, as fundamental rights, are dealt with in articles 40 to 44 These are a matter initially for the Oireachtas, but ultimately for the people. ${ }^{81}$ I discount, though the NIHRC may not, major amendments to Bunreacht na hÉireann.

\section{(vii) The NI Assembly}

The NIHRC, strangely, assumes a NI Assembly will be a permanent feature, and available for BOR amendments. If it is not there, then, under clause 19(1), there can be no amendments. The Northern Ireland Assembly was suspended indefinitely on 12 February 2000, and restored on 30 May 2000. The Northern Ireland Act 2000 was also used, to bring about two shorter suspensions in 2001. As noted above, the United Kingdom government retains powers over the fate of the Assembly. For no other reasons, it would not be possible to have entrenchment and amendment rooted in such a devolved institution.

\section{(viii) Implications for the Irish government}

The NIHRC's draft BOR has major implications for the Irish government. This is for two related reasons.

76 Art 15.2.2.

77 Art 28.3.3.

78 This is recognized, inter alia, in para 33 of Strand One of the Belfast Agreement.

79 Calvert, Constitutional Law in Northern Ireland: a study of regional government (London, 1968), pp 25-29.

80 Paras 3(c) and 22(b) of sch 2.

81 Arts 46 \& 47. 
First, under the first paragraph 9 of the Rights, Safeguards and Equality of Opportunity section of the Belfast Agreement, the Republic of Ireland is required to provide "an equivalent level of protection of human rights as will pertain in Northern Ireland." Reference is made also to "measures to strengthen and underpin the constitutional protection of human rights." So, if the NIHRC is to succeed with its BOR in NI, and the Republic of Ireland is to implement its few international obligations under the Belfast Agreement, the 164 draft clauses will have to be added to the fundamental rights in Bunreacht na hÉireann.

Second, the NIHRC refers to the need for a new international agreement. This is correct, but not in the way envisaged. The Making commentary refers to entrenchment of the BOR in a London/Dublin treaty. ${ }^{82}$ This is not possible, given continuing UK sovereignty. The NIHRC is planning for permanent joint sovereignty, even given NI's transfer from the United Kingdom to the Republic of Ireland! However, a new international agreement is necessary, to complete the constitutional provisions of the Belfast Agreement. Legal cession is not fully provided for in annexes A and $\mathrm{B}$ of the Constitutional Issues section. ${ }^{83}$ There would, therefore, have to be a new United Kingdom/Irish international agreement to bring about a united Ireland. That only shows how far the NIHRC, with talk of a new bilateral treaty, is outside the Belfast Agreement.

The way to guarantee the BOR in a NI under Republic of Ireland sovereignty would be to have it incorporated now in Bunreacht na hÉireann. It would apply to the 26 counties. When the two parts of Ireland were reunited (a most unlikely eventuality), there would be the BOR in NI law (originally from Westminster), and the same instrument in the Irish constitution, courtesy of the people of the Republic of Ireland. The constitution would be amended to define Ireland as 32 counties. The original BOR from Westminster would, now through Bunreacht na hÉireann, continue to apply in NI.

The fact that the Republic of Ireland has to have the BOR at the same time as NI, and the NIHRC has spotted the need for a new London/Dublin agreement (but misunderstood its content), brings us to the same point. This point is simply one of political wishful thinking, with the aim of a united Ireland overshadowing the constitutional provisions of the Belfast Agreement, and the desire for a comprehensive BOR being illegitimately read into a document, which remains little understood.

The chances of the Republic of Ireland adopting the NIHRC's BOR are nil. That means there is no guarantee that NI would be so covered if it were absorbed into the Republic of Ireland. That's also why Dublin, which has interfered in the running of the NIHRC, is now promoting an unenforceable all-Ireland charter of rights as a practical alternative to the BOR in NI. ${ }^{84}$

82 Pp $19 \& 107$.

83 Austen Morgan, The Belfast Agreement: a practical legal analysis (London 2000), pp 144-5.

84 Under the first paragraph 10 of the Rights, Safeguards and Equality of Opportunity section of the Belfast Agreement. 
The answer, of course, to human rights protection in both parts of Ireland is: the ECHR in United Kingdom law, and in the Irish constitution (as required by the Belfast Agreement); and the EU Charter of Fundamental Rights (which applies throughout Ireland, but is not yet - and may not - be incorporated in the European treaties).

\section{(2) The obligation in the Belfast Agreement was to request advice on the scope for particular supplementary rights, not give the Northern Ireland Human Rights Commission carte blanche to draft a comprehensive bill of rights}

Human rights are dealt with in the Belfast Agreement in the section headed Rights, Safeguards and Equality of Opportunity ${ }^{85}$ (which is divided into a Human Rights subsection and one on Economic, Social and Cultural Issues $\left.^{86}\right)$. But there are also important references to a BOR in Strand One, paragraphs 5(b)-(c), 11 and 26(a). Given that the Belfast Agreement is a bilateral international agreement, these paragraphs fall to be construed under articles 31 to 33 of the 1969 Vienna convention on the law of treaties (with article 2 of the British-Irish Agreement ["BIA"] being decisive). Article 31(1) reads: "A treaty shall be interpreted in good faith and in accordance with the ordinary meaning to be given to the terms of the treaty in their context and in the light of its object and purpose."

These are the references to a BOR in the Multi-Party Agreement (MPA) part of the Belfast Agreement (with [deletions] from and additions to the Mitchell Draft Paper of 6 April 1998 shown thus):

\section{STRAND ONE}

\section{Safeguards}

... 5. There will be safeguards ... including: ...

(b) the European Convention on Human Rights (ECHR) and any Bill of Rights for Northern Ireland supplementing it . . .

(c) arrangements to provide that key decisions and legislation are proofed to ensure that they do not infringe the ECHR and any Bill of Rights for Northern Ireland; . . .

\section{Operation of the Assembly}

11. The Assembly may appoint a special Committee to examine and report on whether a measure or proposal for legislation is in conformity with equality requirements, including the ECHR/Bill of Rights ...

\section{Legislation}

[21.] 26. The Assembly will have authority to pass primary legislation for Northern Ireland in devolved areas, subject to:

\footnotetext{
85 Note the concept.

86 Note the word "rights" has been avoided.
} 
(a) the ECHR and any Bill of Rights for Northern Ireland supplementing it...

\section{RIGHTS, SAFEGUARDS AND EQUALITY OF OPPORTUNITY...}

\section{United Kingdom legislation}

2. The British Government will complete incorporation into Northern Ireland law of the European Convention on Human Rights (ECHR)...

4. The new Northern Ireland Human Rights Commission (see paragraph 5 below) will be invited to consult and to advise on the scope for defining, in Westminster legislation, rights supplementary to those in the European Convention on Human Rights, to reflect the particular circumstances of Northern Ireland, drawing as appropriate on international instruments and experience. These additional rights to reflect the principles of mutual respect for the identity and ethos of both communities and parity of esteem, and - taken together with the ECHR - to constitute a Bill of Rights for Northern Ireland. Among the issues for consideration by the Commission will be:

- the formulation of a general obligation on government and public bodies fully to respect, on the basis of equality of treatment, the identity and ethos of both communities in Northern Ireland; and

- a clear formulation of the new rights not to be discriminated against and to equality of opportunity in both the public and private sectors.

\section{New Institutions in Northern Ireland}

5. A new Northern Ireland Human Rights Commission, with membership from Northern Ireland reflecting the community balance, will be established by Westminster legislation, independent of Government, with an extended and enhanced role beyond that currently exercised by the Standing Advisory Commission on Human Rights, to include keeping under review the adequacy and effectiveness of laws and practices, making recommendations to Government as necessary; providing information and promoting awareness of human rights; considering draft legislation referred to them by the new Assembly; and, in appropriate cases, bringing court proceedings or providing assistance to individuals doing so.

In Strand One, there are four references to a BOR, all in the context of the ECHR: paragraphs 5(b) and (c), 11 and 26(a). In two of those (paragraphs 5(b) and 26(a)), the BOR is described as supplementing the ECHR. The term "any" is also used of the BOR in three of those references. (Paragraph 11 - dealing with equality requirements - was added to the Mitchell Draft Paper, and nothing may be inferred from the absence of an "any" in the abbreviated "ECHR/Bill of Rights" phrase. It was a consequence of hasty drafting.) 
The Rights, Safeguards and Equality of Opportunity section of the Belfast Agreement deals with the possible BOR in the first paragraph 4 under the subheading, United Kingdom Legislation, in the context of the incorporation of the ECHR (the first paragraph 2). Its hypothetical nature is clear from the first paragraph 4: one, (presumably) the Secretary of State invites the NIHRC to consider a BOR; two, the NIHRC must first consult (a provision added to the Mitchell Draft Paper); three, the role of the NIHRC is to advise the Secretary of State (and therefore the United Kingdom government); and four, the advice is "on the scope for defining, in Westminster legislation, rights supplementary to those in the European Convention on Human Rights". The key words are "scope" and "supplementary", and the first is a condition precedent for the second.

Significantly, there is no reference to a BOR in the first paragraph 5, dealing with the continuing functions of the NIHRC.

The legal analysis proceeds through the following three, or, if necessary, four stages.

\section{(i) The duties of the NIHRC}

The law governing the functions of the NIHRC, a statutory body, is contained in section 69 of the NIA 1998. The relevant provision is section 69(3)(a): "The Commission shall advise the Secretary of State. . . as soon as reasonably practicable after receipt of a general or specific request for advice;". Here, the issue is a specific request. Section 69(3)(b) - "on such other occasions as the Commission thinks appropriate" - has no relevance. The NIHRC only has the power of initiative under paragraph (b) in the absence of a Secretary of State request. Here, it never had the power of initiative under the NIA 1998, because of the Belfast Agreement.

\section{(ii) The obligations of the United Kingdom state}

These are contained in the extracts from the Belfast Agreement quoted above. This binds the United Kingdom state only, meaning, in domestic law, central government. The first paragraph 4 of the Rights, Safeguards and Equality of Opportunity section makes clear where, in domestic law terms, the duty lies: "The new Northern Ireland Human Rights Commission...will be invited to consult and to advise. ..". In international law, the obligation is that of the state; in domestic law, the duty is upon the Secretary of State. The word "invite" is important.

The relevant paragraph of the Belfast Agreement has been incorporated by reference in the NIA 1998: "The Secretary of State shall request the Commission to provide advice of the kind referred to in paragraph 4 of the Human Rights [sub]section of the Belfast Agreement." This makes clear that the initiative lies with the Secretary of State. It imposed a duty upon him (or her in this particular case).

\section{(iii) The Secretary of State's letter of 24 March 1999}

Within a month of establishing the NIHRC, the Secretary of State wrote to the Chief Commissioner. The letter was not released at the time (there were six Northern Ireland Office press releases that day, including one on head lice!). However, it has been extracted recently through questions in Parliament. 
The Secretary of State played a straight bat, referring to the Belfast Agreement (sic) and the NIA 1998. She stated that she was writing, as required under section $69(7)$, "to invite you to provide advice of the kind referred to in paragraph 4 of the relevant section of the Agreement". She ended the letter: "The Act does not set a time limit for those proposals, and I am sure that you will want to consult widely. I look forward to receiving your advice in due course." As far as the Secretary of State was concerned and she was correct - the United Kingdom government discharged its obligations under the Belfast Agreement, as incorporated by the NIA 1998, ${ }^{87}$ fully in this regard on 24 March 1999, upon the despatch of the letter to the Chief Commissioner.

If the Secretary of State had refused to seek such advice, then arguably the NIHRC could have reverted to its power of initiative under section 69(3)(b) of the NIA 1998. The NIHRC, however, could not have put itself in the Secretary of State's place as regards the Belfast Agreement.

\section{(iv) Was the NIHRC confused in March 1999 as to the nature of the request?}

I don't believe this for one moment. The BOR had been a CAJ project. Despite the HRA 1998, the slight reference in the Belfast Agreement was used by the CAJ-dominated NIHRC as the hook to launch its project: a NI rival to new Labour's HRA 1998. And this despite the fact that the NI political parties had always understood, by a BOR, the incorporation of the ECHR - which had taken place with royal assent on 9 November 1998 (even though it would not come into force fully throughout the United Kingdom until 2 October 2000).

The Secretary of State had quoted from the first paragraph 4, from "to consult and to advise" to the phrase "to constitute of (sic) Bill of Rights for Northern Ireland". If the NIHRC had been confused, it could have done one, two or three things:

- entered into correspondence with the Secretary of State, as to the meanings of "consult", "advise", "scope" and "supplementary". This did not happen. However, there is an intriguing reference on page 14 of Making to the views of the United Kingdom government (this being a letter from No. 10 to the NIHRC);

- $\quad$ sought independent legal advice, ideally not from within the human rights community, but from independent specialist counsel in Belfast or London. I do not know if this was considered;

- $\quad$ arranged a friendly legal action, such as summary disposal on a point of law, or an application for judicial review, in the High Court in Belfast, which would have given the NIHRC legal immunity (if successful), and credibility, for the project it embarked upon, involving considerable public resources of time, persons and money.

87 The first paragraph of the letter is legally correct, even if "commitments" is not exact: "The Northern Ireland Act 1998 which established the Northern Ireland Human Rights Commission implements the commitments in the Rights Safeguards and Equality of Opportunity section of the Belfast Agreement." 
The NIHRC has already been down the ultra vires road. Section 69 of the NIA 1998 makes no reference to the power to intervene as a third party in legal actions ${ }^{88}$. The NIHRC, however, proceeded to do this. ${ }^{89}$ The courts quickly restrained it. When it was refused permission to intervene in the Omagh inquest, the NIHRC applied for leave to apply for judicial review. It secured leave. Sir Robert Carswell LCJ, at first instance, held third-party intervention was ultra vires the NIA 1998. This was upheld in the Court of Appeal, Kerr J dissenting. ${ }^{90}$ The NIHRC has secured leave to appeal to the House of Lords.

\section{(3) Even if this had been in the Belfast Agreement, it would be irresponsible to scatter a cornu copia of badly formulated rights into a communally divided society with little instinct for democracy}

There are two ideological views about rights in NI. The first is that of the human rights community. It believes that, if it had had its way, the troubles in NI would never have taken place. ${ }^{91}$ Such counter-factual history is difficult to justify. This view may be characterized as self-serving. The second is that of the government of the United Kingdom, which gave further effect to the ECHR in domestic law through the HRA 1998. This is the view that rights are integrally related to responsibilities. It is, indeed, inherent in the structure of Convention rights: a right followed in many instances by a limitation; the individual benefits from living in a democracy, but also contributes to others in society.

Individual, or human, rights are essential to civilization. They are integral to the rule of law. But any society needs a thriving economy. And it can only determine public policy through a functioning democracy. That requires political representation, with a subordinate role for the self-interested elements of civil society.

NI is very far from this ideal. Three decades of political violence have taken their toll. Direct rule had the consequence of creating, what some consider, a quasi-colonial system of government based on the Northern Ireland Office. A huge dependency culture was created. Republican, and loyalist, terrorists were able to frustrate normal political activity. Politics was dominated by communal rivalry and this continues under devolution. Self-appointed social forces have substituted for elected politicians, with political correctness interlocking with (Catholic and Protestant) sectarian consciousness.

88 The powers are limited by ss $69(5)$ (a) \& 70 (assistance to individuals) and s69(5)(b) (bringing proceedings in its own name).

89 Re Treacy's and another's Application for Judicial Review [2000] NI 330; In the Matter of an Application by Evelyn White for Judicial Review, judgment of Carswell LCJ, 18 May 2000; Re Adams's Application for Judicial Review [2001] NI 1.

90 In the Matter of an Application by the Northern Ireland Human Rights Commission for Judicial Review, Carswell LCJ, 8 December 2000; CA (NI), 6 April 2001.

91 See the view of Professor Kevin Boyle, at the launch of the draft BOR, 4 September 2001 (supplied text). 
The Belfast Agreement of 10 April 1998 is considered to be the only solution. This is certainly the view of the United Kingdom government, which retains the responsibility for NI. But it is also the view of the Irish government. It is relieved to have power without responsibility, and has helped mythologize what it calls the Good Friday Agreement. Part of this romanticization of politics includes a folksy - or, in David Kennedy's words, sloppy - concept of human rights. Whatever the problem, there is a human rights solution. The result has been the massive overkill of Making a Bill of Rights for Northern Ireland, related to the interventionism of the NIHRC in a myriad of problems, to little constructive effect.

It is, therefore, necessary to get back to what the Belfast Agreement is, fully cognizant of the fact that pan-nationalism has culturally appropriated it, antiagreement unionism essentially accepts this claim, and pro-agreement unionism has not asserted a pragmatic political interpretation compatible with the rule of law.

The Belfast Agreement comprises two texts: the MPA and the BIA. Their relationship is little appreciated (pro- and even anti-agreement commentators adopting a literal, almost biblical, approach to the text of what they call the Good Friday Agreement). Cm 3883 of April 1998 (presented to Parliament by the Secretary of State for Northern Ireland as the Belfast Agreement) has the BIA annexed to the MPA. ${ }^{\mathbf{9 2}}$ The relationship was altered in Cm 4292 of March 1999 and Cm 4905 of May 2000 (both presented by the foreign secretary), the MPA becoming annex 1 of the BIA in accord with the text of the latter. ${ }^{93}$

The Belfast Agreement, as a bilateral international agreement between the United Kingdom and Irish states, entered into force on 2 December 1999. The conditions precedent in article 4 of the BIA determined its effect immediately after 10 April 1998. Upon entry into force, the two states parties were bound by the BIA, and, under article 2, but only "where appropriate", the MPA in annex 1.

There have been repeated references to the participants in the 1996-98 multiparty negotiations signing up to the Good Friday Agreement. This claim fails to distinguish the two contracting states and the NI political parties. It also neglects to appreciate that Sinn Féin did not even vote on 10 April 1998 for the MPA (and it never subsequently endorsed the Belfast Agreement). ${ }^{94}$ The other political parties did vote for the MPA under the rules of the multiparty talks, which came to an end on Friday, 10 April 1998. So also did the United Kingdom and Irish governments (but to no legal effect). Tony Blair and Bertie Ahern, and, though it was unnecessary under the law of treaties and their respective constitutions, Mo Mowlam and David Andrews, signed the BIA at the end of the talks - without, I believe, the MPA being annexed to the vellum copies.

92 This was the text voted upon in NI on 22 May 1998 (see paragraph 2 of the Validation, Implementation and Review section).

93 Respectively, the country series (before entry into force) and the treaty series (after entry into force).

94 Austen Morgan, The Belfast Agreement: a practical legal analysis (London 2000), pp x-xii. 
The Belfast Agreement binds the two states parties. This contains four types of text: one, international obligations, binding on one or both states parties; two, terms implied by international law, both general and particular; three, political text; and four, rhetoric. (The references to a BOR, as argued above, amounted to the Secretary of State requesting advice from the NIHRC, and thereby discharging the United Kingdom's international obligation.) An important implied term is the principle of legality in international law. An example of political text is the section on policing and justice, with "a new beginning" being nothing other than a literary flourish. The Belfast Agreement binds the NI parties politically (for what that is worth), more particularly by what I call its political face. But domestic NI law also binds them. This also includes a principle of legality. If it did not, there would be no constitution. On, for example, the dominant issue of decommissioning, the Belfast Agreement (governed by the law of treaties) did not alter the domestic law of NI, to the effect that the Irish Republican Army ("IRA") remains an illegal organization in possession of illegal arms. The international and domestic provisions for amnesty relate only to the handover and/or destruction of weaponry. ${ }^{95}$ The Belfast Agreement does not provide that the IRA may hold on to its weapons, until such time as Sinn Féin achieves what it considers the full implementation of the Good Friday Agreement.

In The Belfast Agreement: a practical legal analysis (2000), I discussed in the preface a special issue of the Fordham International Law Journal (book 4 of volume 22, April 1999). I characterized the - mainly nationalist, republican or radical - academic contributors as espousing a political triptych instead of a legal analysis of the Belfast Agreement, involving: one, a constitutional weakening of NI's position within the United Kingdom; two, a major all-Ireland institutional advance; and especially three, the centrality of unspecified human rights. "Nationalist Ireland", I wrote, "is telling itself it has made a structural advance beyond the 1920-22 partition settlement." 96 This is not the place to rehearse such general issues, save to say that my practical legal analysis is countered with three alternative propositions: one, the constitutional sections are characterized predominantly by the end of the Irish territorial claim; two, the most important sections are those dealing with the institutions, most particularly the Strand One devolution settlement; and three, the HRA 1998, and article 13 of the European Community treaty, inserted by the 1997 Amsterdam treaty, were much more significant than the human rights community in NI.

Sinn Féin would have none of this, and it has managed to dominate adversely the implementation of the Belfast Agreement since 1998. It originated "the Irish peace process" in the late 1980s, meaning Brits out and a united Ireland. And it formulated the pan-nationalist strategy. The IRA's 1997 ceasefire, a restoration of the complete cessation of 1994 (which the republicans broke),

95 Agreement between the Government of the United Kingdom of Great Britain and Northern Ireland and the Government of the Republic of Ireland establishing the Independent International Commission on Decommissioning (Cm 3753); Northern Ireland Arms Decommissioning Act 1997; the Republic of Ireland's Decommissioning Act 1997; plus secondary legislation, including decommissioning schemes and regulations.

96 P xvii. 
has been observed only as regards the police and the army. ${ }^{97}$ Sinn Féin characterized the Belfast Agreement as transitional to a united Ireland, and then, by invocations such as "the agreement" and "Patten", has managed to reconcile revolutionary absolutism and democratic participation - this being tolerated by an appeasing United Kingdom government, at the behest of the Irish government, and with constitutional parties playing supporting roles in the power-sharing administration.

It is this political uncertainty, which has allowed the NIHRC to thrive. It has not behaved properly as a public body (part of the state), making a constructive contribution to the problem of communal division. The NIHRC has conducted itself as a radical group, failing to work with other public authorities. It has engaged in posturing, of dubious human rights significance. The fact that some of the commissioners would deny this strongly only strengthens the criticism. Whatever internal differences may exist in the NIHRC, no sensible element had emerged by 4 September 2001, sufficiently to prevail over the radicals among the commissioners and their staff.

The NIHRC has majored in the BOR project. To some extent, the 1999 commission seemed determined to realize its goal before the end of its threeyear period (its reappointment may lead to a revised strategy). However, the NIHRC's lack of political realism suggests continuity with the CAJ days. Then, a BOR, despite moments of rationality ${ }^{98}$, was put forward as a Utopian panacea. Since 1999, the NIHRC has attempted populist mobilizations. Commissioners imply that everyone will gain more rights, through their BOR rather than the courts administering the HRA 1998. The corollary also applies: there has been an extraordinary attempt in Making to play down what Strasbourg considers a right fundamental to a democratic society, because the loyal orders, while they hesitantly invoke article 11 of the ECHR (peaceful assembly), have not looked (quite reasonably) to the NIHRC to resolve the issue of parading. ${ }^{99}$

This scenario was never envisaged by the NIO, which brought the NIHRC into being and keeps it alive. Such radical conduct is inconsistent with the Belfast Agreement. But this major latter attempt to settle NI has only increased communal division, with over-confident nationalists confronting alienated unionists. A still revolutionary Sinn Féin, in word but also in disciplined deeds, is a necessary condition for such human rights activity. The NIO has used "human rights" to lure republicans into the shallow water of democratic management, indulging the NIHRC because of United Kingdom state interests. The BOR will become a cause when Sinn Féin discovers the grievance of its non-appearance ${ }^{100}$, in the next series of

97 Andrew Rawnsley, Servants of the People (London 2001), p 123.

98 Brice Dickson, "What practical difference would a Bill of Rights make in Northern Ireland?" June 1994 typescript.

99 Clause 12 (heading); Making, pp 77-78; NIHRC minutes, 12 March 2001.

100 Sinn Féin has said remarkably little about a BOR. It was not interestingly included in the two governments' "take or leave it" document of 1 August 2001 which resulted from the Weston Park talks. For an indication of the likely response, see Michelle Gildernew: www.utvinternet.com, 4 September 2001. 
demands it will make, supposedly in return for further action on decommissioning.

The NIHRC described its proposals as "radical and wide-ranging"101. As a political project, the draft BOR is amazing. It represents a fusion of: a quasireligious worldview, in which theology has been replaced by "international human rights standards" (a confusing phrase); ${ }^{102}$ a central role has been created for a secular clerisy, with the NIHRC at the head of a charismatic movement; the outturn being a degree of state intervention in civil society reminiscent of twentieth-century communism, or aspects of post-world-wartwo European social democracy.

In 2000, the House of Lords select committee on the European Union ("EU"), in a report on the (as yet non binding) EU Charter of Fundamental Rights, concluded of economic and social rights (which the NIHRC sees as a key aspect of its BOR): "No Member State or other common law country to the best of our knowledge has a charter of rights which goes beyond the basic civil and political rights, apart from some limited additions dealing with discrimination, rights to freedom of association and some "directive principles" to inform policy-making in the socio-economic field. . . This suggests to us that economic and social rights that are not justiciable should be put in a different chapter of the Charter [if incorporated in the treaties] so that its status, as compared to the core civil and political rights, is made clear." 103

Among the maximalist demands of the NIHRC are:

- electoral rights ${ }^{104}$, including (unrepealable) proportional representation, the possibility that NI MPs might have to be included in a United Kingdom (or Irish) government, and voting and representing for children at 17 years (or conceivably younger) in $\mathrm{NI}^{105}$; these, of course, are political issues and not questions of right;

- identity and communities, the issue on which the NIHRC was asked to advise: the term "parity of esteem" has been rejected ${ }^{106}$ (though unionism needs to be treated equally with nationalism); however, nationality has been turned into a question of fundamental law (for the United Kingdom and the Republic of Ireland), reverse political

101 Supplied text, 4 September 2001.

102 Thus the preamble refers to the EU's Charter of Fundamental Rights. This, of course, has not (yet) been incorporated in the European treaties.

103 House of Lords, 1999-2000, Select Committee on the European Union, $8^{\text {th }}$ Report, EU Charter of Fundamental Rights, p 37. See also, Robert Blackburn, Towards a Constitutional Bill of Rights for the United Kingdom (London 1999), pp 49-50. The Bangalore Principles (for common law jurisdictions) also exclude economic, social and cultural rights in the main: [2001] EHRLR 273 at 288

104 Part of the democratic rights chapter. This begins with a paragraph replete with major errors: Making, p 20.

105 The criticism has been made that any such change in the voting age would have the sudden effect of boosting the nationalist vote. The point has also been made that the BOR might prevent a voting age lower than 17 years.

106 It survives in an alternative. A moment of rationality descended when the NIHRC wrote: "It is hard to envisage how the Government could guarantee that the two communities feel respected by each other." (Making, p 25) 
discrimination ("representivity") has been parenthetically trailed, the Framework Convention for the Protection of National Minorities has been incorporated in part (contrary to the advice of the Council of Europe ${ }^{107}$ ), travellers (new age and otherwise) have been recognized, and public authorities have been given the duty to "preserve" minority cultures;

- a quasi-communist equality agenda, based on equality of outcome, and reverse discrimination, ${ }^{108}$ which subverts NI and European Community anti-discrimination law, and the equality of opportunity vision of the Belfast Agreement;

- a shell for women's rights, which only cross-refers to four other chapters;

- dissolution of the institution of marriage, in favour of the rights and responsibilities of all "long-term domestic partnerships";

- children's rights (29 of the 164 clauses), with a child being defined as under 18 years, including raising the age of criminal responsibility to 12 years (and abolishing juvenile justice); there is a direct horizontal effect uniquely in this chapter; there is also, apparently, a "right to play";

- $\quad$ education rights: while the BOR sends out separatist signals - "religious ethos", "Irish-medium education" - in the commentary the NIHRC states it is opposed to the continuing exclusion of teachers from fair employment legislation; however, "genuine occupational requirement", in the context of recent EC anti-discrimination law (which has not been absorbed properly), would amount to the status quo prevailing;

- language rights: again, the Charter for Regional or Minority Languages is unnecessarily incorporated, part IV providing for an adequate international reporting mechanism, involving a committee of experts within the Council of Europe;

- $\quad$ social, economic and environmental rights (20 of 164 clauses), including health care, adequate standard of living, housing, work, and healthy and sustainable environment; these are clearly intended to be legal rights, given the references to "legal remedies", "judicial and administrative procedures", "fair legal process", and, in chapter 18 (enforcement), compensation and other court orders; and this despite the specific interpretative approach requiring public bodies to "take legislative and/or other measures to develop and enforce programmatic responses to the social and economic rights set out below.";

107 Paragraph 11 of the explanatory report accompanying the Convention reads: "In view of the range of different situations and problems to be resolved, a choice was made for a framework Convention which contains mostly programme-type provisions setting out objectives which the Parties undertake to pursue. These provisions, which will not be directly applicable, leave the States concerned a measure of discretion in the implementation of the objectives which they have undertaken to achieve, thus enabling them to take particular circumstances into account."

108 "full and effective equality. . . by reducing inequalities affecting groups disadvantaged on the grounds specified. . or on socio-economic grounds". 
- there are no limitations in the individual chapters, but, in chapter 16 , there is a general limitation clause similar to that in the CAJ's 1993 BOR;

- finally, on the right to life, the BOR is concerned only with violations of article 2. Nothing is offered by way of a horizontal effect (as in the children's chapter). Terrorists, however, have an additional 127 clauses And "law enforcement official[s]" have further restrictions imposed upon them. As for article 5 (liberty and security), the three existing clauses are expanded to 17 . Twelve new clauses are added to the existing three in article 6 (right to a fair trial).

Most of these issues (except for the last two) are the stuff of politics, for political parties with electoral programmes. Unfortunately, the NI Assembly has yet to mature. It remains attached to an inclusive, but Balkanized, system of government. Departments have become party fiefdoms; there is no opposition worth mentioning, and very little accountability. Involuntary coalitionism could only ever have been for a transitional period. However, there is little sign of a - centre against the sectarian extremes - voluntary coalition being constructed between the UUP and the SDLP.

This immaturity of politics is related to the naivety of the human rights community. Its strength is, in fact, the weakness of the democratic system. Neither the persons, nor the ideas, would have achieved such apparent stature anywhere else in the United Kingdom or mainland Europe.

\section{(4) Northern Ireland's Bill of Rights is the Human Rights Act 1998, and a framework for the future by amendment at Westminster}

The HRA 1998 is of major legal significance. It is, undoubtedly, here to stay. Part of its significance stems from directly justiciable human rights. But parliamentary counsel was commended in Parliament, for the way further effect had been given to a multilateral agreement in domestic United Kingdom law.

The HRA 1998 - following the New Zealand Bill of Rights Act of 1990 does not, of course, strictly incorporate the ECHR; the rights remain in international law, subject to possible derogation and reservation. It is the remedies - not the rights - that have been brought home metaphorically. Domestic courts have now replaced Strasbourg to a considerable extent, though the European Court of Human Rights will still consider the United Kingdom's obligations under the ECHR. The HRA 1998 is largely an interpretative measure; the jurisprudence of Strasbourg is now infusing United Kingdom law, and, a point made much of in 1997, United Kingdom judges are able to help shape human rights legal culture in Europe. It has been described by Lord Lester of Herne Hill QC (as he now is) as "the most significant constitutional measure since the Bill of Rights of 1688-89 (apart from the European Communities Act in the areas where it reigns supreme)." ${ }^{109}$

109 Counsel, December 1999, pp 20-22. 
Under the HRA 1998, in private-law litigation between parties, the court now has to take account of Convention rights.

This is because of section 6 (acts of public authorities). Subsection (1) states: "It is unlawful for a public authority to act in a way which is incompatible with a Convention right." Subsection (3) defines a public authority as including a court or tribunal (or a person exercising functions of a public nature), but neither house of Parliament. Thus, a court, whether civil or criminal, is required by the HRA 1998, to act in a way that is compatible with a Convention right. (Section 2 requires the court, in interpreting the Convention right, to take into account inter alia the jurisprudence of the Strasbourg Court.)

Section 7(1)(b) states that a person may rely upon a Convention right in any legal proceedings. It is possible - given this express (albeit indirect) horizontal effect (mentioned above) - to proceed against a non-state human or legal person in private law, and have the court find a breach of a Convention right (this is possible in the United Kingdom; not in Strasbourg). ${ }^{110}$

Section $8(1)$ allows the court to grant such relief or remedy, or make such order, within its powers, as it considers just and appropriate. ${ }^{111}$ "English law", as Lord Wilberforce once said, "fastens not on principles but on remedies." 112

The current Lord Chief Justice, Lord Woolf, wrote in 1999 of the creation of human rights torts in both public and private law: "These torts will redefine the relationship between the individual and the State but will go beyond this by operating "horizontally" to influence the rights of individuals as well. The interests of minorities will be protected in a way which, up to now, has not been possible." $" 113$

The HRA 1998, as an act of the Westminster Parliament, applied presumptively to the whole of the United Kingdom. For the avoidance of doubt, section 22(6) states that the act extends to NI. NI, therefore, was to have exactly the same legal regime as England \& Wales and Scotland.

This was clear to the drafter of the Belfast Agreement, but the form of incorporation - remedies not rights - was not. The Human Rights Bill had been introduced in the House of Lords in October 1997, and debated there until February 1998. On 10 April 1998, the Bill was before the House of Commons. ${ }^{114}$ However, no specific reference is made to the Bill in the Belfast Agreement. The first paragraph 2 of the Rights, Safeguards and Equality of Opportunity section refers to completing the incorporation of the ECHR (which was not strictly correct). So also does paragraph 4, where the BOR for NI is defined as the ECHR plus any supplementary rights accepted

110 See also s 22(4).

111 Query: if there is a private defendant, could damages be awarded against a (nonappearing) public authority?

112 Davy v Spelthorne BC [1983] 3 All ER 278, 285.

113 Lord Lester of Herne Hill QC \& David Pannick QC, Human Rights Law and Practice (1999), p vii.

114 It had had a second reading on 16 February 1998. The committee stage followed on 20 May 1998. 
by the United Kingdom government. (Strand One refers similarly to the ECHR.)

The references to a BOR in the Belfast Agreement must therefore be interpreted legally in terms of the human rights regime that has prevailed throughout the United Kingdom since 2 October 2000. It cannot be used to justify a full incorporation of the ECHR, if only in NI.

Section 1(1) of the HRA 1998 defines what are called Convention rights, citing their source in the multilateral ECHR. These are also reproduced in schedule 1 of the HRA 1998. It therefore follows that the act may be amended to embrace further Convention rights simply by adding to section 1(1). Section 1(4)-(6) allows the Secretary of State to add by order an ECHR protocol that has been signed or ratified. Rights from other international instruments would require a new section $1(1)(\mathrm{A})$ by primary legislation, plus inclusion also in schedule 1. They would not be justiciable in Strasbourg, unlike the Convention rights. Amendment of the HRA 1998 is the most obvious way to improve the protection of human rights in United Kingdom law throughout the state. There is no technical obstacle to specific NI rights. They could also be added to the HRA 1998. And they would not be justiciable at Strasbourg.

It is another question whether there should be specific NI rights.

The NIHRC was set up to promote human rights. While section 69(10)(b) of the NIA 1998 allows for the advocacy of additional rights, other Commission functions require knowledge of human rights as existing legal entitlements.

\section{CONCLUSION}

Each of the above four arguments stands on its own. Argument (3) (if a BOR had been in the Belfast Agreement) is the most speculative. It is premised on something that does not exist. However, it is the point where I have engaged the NIHRC most directly. The Commissioners, wanting a BOR for NI, simply joined in distorting the Belfast Agreement into a Good Friday Agreement, which says what some people want it to say. The other three arguments involve more legal and constitutional analysis.

Argument (1) (shattering United Kingdom human rights protection) goes to the heart of the matter: where NI is located constitutionally. The NIHRC's single-minded ignoring of Great Britain is related to its dependence upon Irish nationalism. (I have not addressed that issue directly, with comments on the totemic joint committee between the NIHRC and the Irish HRC in the first paragraph 10 of the Rights, Safeguards and Equality of Opportunity section of the Belfast Agreement. It suffices to mention, that the NIHRC's intuitive anti-state sentiment when it comes to the United Kingdom, is not carried over to the Republic of Ireland, despite the internationalist character of universal human rights.)

Arguments (2) and (4) (respectively, the actual obligation in the Belfast Agreement, and the HRA 1998 is NI's BOR), are symmetrical. The NIHRC was asked to do something. This it ignored. It then went on to do what it wanted. And, in the process, ignored the importance of new Labour's constitutional contribution in the form of human rights protection. In doing both, it revealed remarkable legal incompetence - its inability to interpret a bilateral international agreement, and a United Kingdom statute, which 
resolves the relationship between international and domestic law as regards individual human rights.

What about the provisions of the first paragraph 4 of the Rights, Safeguards and Equality of Opportunity section? And what should be done about the NIHRC?

\section{An Assembly human rights committee}

I propose that the problem now be handed to the NI Assembly. There is a precedent: the joint human rights committee at Westminster. This was an alternative to a Human Rights Commission in GB. However, it may be followed in NI.

The joint Human Rights Committee was not established until the last session of the 1997 Parliament. It held its first meeting on 31 January 2001. Its chairman was (and remains) a Labour MP, Jean Corston. Among the 11 other members were: Desmond Browne MP (now a junior NIO minister); and Lord Lester of Herne Hill QC and Lord Goldsmith (now the Attorney General for England and Wales and also, for the moment, NI). The committee's terms of reference are: "to consider matters relating to human rights in the United Kingdom (but excluding consideration of individual cases)". It could, for example, enquire into the NIHRC. Before the end of the 1997 Parliament, it rushed out three reports. ${ }^{115}$ This work has continued in the 2001 Parliament, commencing with an important report on the Antiterrorism, Crime and Security Bill ${ }^{116}$.

A human rights committee, with appropriate powers, could be established at Stormont, under paragraph 10 of Strand One of the Belfast Agreement. Standing Order 49, made under the NIA 1998, provides for non-statutory committees, including standing committees. Such a committee could not take over all the functions of the NIHRC in section 69 of the NIA 1998. However, it could do a great deal to monitor human rights law and practice. It would have the virtue, given the rules governing the appointment of Assembly committees, of being politically representative.

\section{A new NIHRC?}

This is quite simply an imperative. An alternative would be the scrapping of the idea altogether, involving an amendment to the NIA 1998. The idea in the Belfast Agreement might encourage the Irish government to cause difficulties. However, Dublin is likely to grow disenchanted with the Irish $\mathrm{HRC}$, and the human rights community in both parts of Ireland might find it less easy to maintain its newfound status.

The NIHRC has lacked public confidence since 1 March 1999. It must be doubted that it was recruited on the basis of merit. A minister defined representativeness, when the Northern Ireland Bill was going through

115 2000-01, First Special Report: Criminal Justice and Police Bill, HL Paper 42/HC 296; Second Special Report: Implementation of the Human Rights Act 1998, HL Paper 66-I/HC 332-I; Third Special Report: Scrutiny of Bills, HL Paper 73/HC 448.

116 2001-02, Second Report: Anti-terrorism, Crime and Security Bill, HL Paper 37/HC 372, 14 November 2001. 
Parliament, as "the broad Unionist community and the broad nationalist community"117. It was not defined in sociological terms: religion, gender, etc. However, that was what was done when the Secretary of State made the appointments.

Lawyers and others less enamoured of the NIHRC were looking forward to a brand new commission on 1 March 2002. Then, one member resigned. In the process of replacing her, three additional commissioners were selected after advertisement. But the remaining nine commissioners were reappointed, in a process lacking in transparency. Most likely, the issue of the NIHRC will lead to litigation: maybe actions based on political discrimination in NI; or, in London, and after complaint to the Office of the Commissioner for Public Appointments, an application for permission to apply for judicial review.

\section{A genuine human rights culture for all}

NI needed human rights protection in 1999. The HRA 1998 should have been its basis. A new legal epoch began on 2 October 2000, and NI should have been aligned with GB.

It will be commensurately more difficult to establish a culture of genuine human rights for all in NI in 2002 and beyond. However, the human rights priorities remain the following:

- action on article 2 (the right to life), as outlined above, namely the develop of the indirect horizontal effect in the HRA 1998. A leading case might well arise from the Real IRA bombing of Omagh on 15 August 1998;

- $\quad$ article 5 (liberty and security, not liberty or security), as a result of 11 September, where the Anti-terrorism, Crime and Security Act 2001 will extend to NI, as will other domestic and European measures;

- article 11 (freedom of peaceful assembly), an issue created by republicans in 1994, and not resolved by the United Kingdom's public order approach, combined with a regulating Parades Commission, which has failed to embrace a genuine human rights approach. There is now another NIO review, and this may well lead to a new approach to the problem, capable of winning the assent of those who wish to exercise this particular human right;

- ECHR protocol no. 12 (the right not to be discriminated against): the United Kingdom is refusing to sign, let alone ratify, this measure, adopted in Rome on 4 November 2000. The most distressing human rights moment since the Belfast Agreement was the Patten report on policing proposal for 50/50 reverse discrimination. This necessitated the disapplication of NI's anti-discrimination law as regards the police, and an opt out in a European directive (also allowing teachers in NI not to benefit from equality protection). The NIHRC (and the Equality Commission) were gung-ho for reverse discrimination in favour of "Roman Catholics" (but not other groups?). Both organizations will

117 Hansard, House of Commons, $6^{\text {th }}$ series, vol. 317, cols 59-60, 27 July 1998. 
have to choose between Patten and protocol no. 12. And, given allegations about lower-merit Catholics being recruited over highermerit Protestants, this issue is likely to end up in the NI courts and the European Court of Justice and/or the European Court of Human Rights.

There is, then, a serious alternative human rights agenda. In seeking to engage it, the human rights community will, most likely, be an obstacle. Given the legal mainstreaming of human rights on 2 October 2000, it is unlikely to be an insuperable one. 